\title{
German Neighbours from Across the River - Insiders? Strangers? Others?
}

\author{
Kamilla Dolińska, Natalia Niedźwiecka-Iwańczak
}

\begin{abstract}
The form of transborder interactions depends inter alia on trust and the convergence of values among neighbouring societies. In addition, cooperation is fostered by the similarity of language and a long history of cross-border contacts and collaboration. The Polish-German borderland emerged as a consequence of border treaties after World War II, and so is an example of a new neighbourhood, because both sides of the border are inhabited by people who settled there after 1945 . There is a significant cultural distance between Poles and Germans. In this article we deal with the question of the perception of Germans by Poles - the attributes that are ascribed to them by the inhabitants of Zgorzelec, Gubin and Słubice. Are the (spatially) closest neighbours still divided by mental barriers? Are Germans judged by stereotypes? Or maybe, as a consequence of the widely undertaken transborder practices, these barriers have been done away with or their importance is diminishing, and with them the distance between Poles and Germans in twin towns?
\end{abstract}

KEY WORDS stranger/other, divided towns, Zgorzelec, Gubin, Słubice, Polish-German borderland, neighbours

Soon after the end of WWII, in the expertise by C. Konczak, a regional plenipotentiary, the situation on the Polish-German border and environs were referred to in the following way: "having bridge outposts on the Odra and Nysa $Ł u \dot{z} y c k a$ rivers" is a warrant for undisturbed possession of the land eastwards of these rivers, especially [by the population] of a markedly defensive character, as Poles are, in opposition to Germans who have always been an aggressive element as for the push eastwards" (quoted in Makaro 2007: 28). More than six decades later it is worthwhile to pose a question: Who are the German neighbours for the inhabitants of the area in the vicinity of the above-mentioned border? This article aims at giving an answer to this question. The theoretical axis around which these considerations are focused is the conception of familiarity and strangeness, as well as the concept of social distance related to that opposition (Nowicka 1991: 176). This inquiry will be accompanied by two research questions referring to two areas - firstly, the perception of Germans by Poles, with particular attention paid to the German neighbours' features, liking them and openness

Sociální studia / Social Studies 1/2017. Pp. 95-116. ISSN 1214-813X.

1 The names of the rivers in the two languages are: "Odra" and "Nysa Łużycka" (Polish) and "Oder" and "Neisse" (German). In the article the Polish names tend to be used. 
to their presence in various roles on the Polish side of the Nysa and Odra Rivers; and, secondly, the perception of "the world across the river" that creates the material surrounding in which the German neighbours live.

\section{Insiders, Strangers, Others?}

Reference to the "Us/Them" dichotomy or, to put it in a different way, "Insiders/Outsiders", has to do with the division of "Outsiders" into "Others" and "Strangers". The difference between these two groups comes down to a perceptive and not valuative aspect of perceiving and classifying people.

In the process of structuring the social world otherness may remain just otherness but it may also turn into strangeness. When, along with realizing dissimilarity, one's feelings start to include a complex of differentiated emotions - a sense of incomprehensibility, awkwardness, the ridiculous as well as unrest, fear or sense of danger or indiscretion - then otherness gathers the traits of strangeness. An observer's indifferent attitude turns into the engaged one, i.e. observation is replaced by evaluation. More precisely, observation gets accompanied by evaluation which from now on will determine the observation itself. [...] Perception of individuals and groups as other, dissimilar or different from us does not necessarily trigger any form of strangeness if it is limited to giving facts and does not engage valuation. The awareness of otherness turns into strangeness only when the emotions and attitudes [of a particular type] combining with the perceived dissimilarity appear. (Nowicka and Łodziński 2001: 34-35)

This can be clearly observed in the context of such evaluations that include an element of unrest, danger. And so the "Stranger" is at present, or potentially, dangerous, poses a threat to the values that are precious for an individual, whereas the "Other" is one whom we do not understand and thus do not accept at all (Kozera 1999: 41), as he/she is not an "Insider". Bearing in mind this kind of valuation of the "Stranger" and the "Other", two things should be underlined: the fact of the existence of the potential to distinguish between these two analytical categories, as well as the validity of this kind of arrangement of reality and the categorizing of particular "Outsiders" (Dolińska and Makaro 2015: 74-75; Dolińska 2016). The description and evaluation that many a times accompanies it and that is expressed in language, becomes a factor (or factors) that precondition the attribution of certain psychosocial features (even on the grounds of a single case) to the representatives of a different culture; these features, in turn, become a premise for initiating, or not, social contacts and, possibly, for building long-term social relations. As it was put by Tadeusz Paleczny: "Linguistic categorization means both psychological and social categorization" (2007: 125).

Such considerations of familiarity, strangeness and otherness lead one to the classical conception of "the stranger" by George Simmel (1950: 402-408). What is important for our attempts to investigate strangeness in a borderland is contact, i.e. being in spatial proximity with a given community and a stranger (or strangers) that poses an indispensable condition for this strangeness to be examined. As Simmel puts it, "He [the stranger] is fixed within a particular spatial group, or within a group whose boundaries are similar to spatial boundaries" (1950: 402). The stranger's status is, however, peculiarly paradoxical as it poses a synthesis of wandering and being settled: the stranger is a specific wanderer - "as the person 
who comes today and stays tomorrow" (1950: 402). As a newcomer or foreigner, the stranger is characterized by his bringing into a group new elements derived from the community he comes from; "his position in this group is determined, essentially, by the fact that he has not belonged to it from the beginning, that he imports qualities into it, which do not and cannot stem from the group itself" (1950: 402). For the stranger is different from the group members in that he is not an "owner of soil" that is connoted "not only in the physical, but also in the figurative sense of a life-substance which is fixed, if not in a point in space, at least in an ideal point of the social environment" (1950: 403).

This incommensurability implies the community's reaction to the stranger assuming the form of repellence, increased distance, and coolness (cf. Simmel's analysis carried out by Marta Bucholc 2010). And this distanced emotional approach to the stranger is the opposite of closer relations connecting group members who appear in their interactions in their individual uniqueness and not as generalized human beings. In contrast, the stranger is taken as a representative of a certain category of a general character, which blurs the stranger's individual features. Although the stranger becomes part of the group's structure, yet he fulfils merely strictly determined roles, accessible to him, located in economic and commercial spheres. No personal, but rather material relations may be formed on the level on which these roles are fulfilled and so one lacks conviction that the persons participating in it are not fungible, irreplaceable. Thus, strangeness is for Simmel a consequence of a specific location within the group structure - the unity of nearness and remoteness.

This clearly structural approach to strangeness (in the perspective of group belonging) is at present untenable (cf. Stichweh 1997; Alexander 2004: 93). However, Simmel's conception contains a possibility to include the cultural factor, which was pointed at by Jeffrey Alexander. Namely, he proposes that, while figuring out the strangeness, one needs to concentrate "on the cultural interpretation of social structures and the categories within which these active interventions are made" (Alexander: 2004: 91). Then a factor different than commonality mentioned by Simmel, namely the construction of difference, would be the one "that makes potentially marginal groups into dangerous ones that are strange" (2004: 91). This means that a sense of strangeness in the eyes of the recipient group is a derivative of employing towards others distinctive standards of interpretation and perceiving these others as polluted and deserving to be repressed (2004: 93). Eventually, in his conception Alexander takes into account both elements, structural and cultural, yet gives primacy to the latter (2004: 102).

A particular context for analysis of intercultural relations and application of the categories of "Insider", "Stranger" but also "Other" is constituted by a borderland. It is an area of radiation, mutual diffusion of multifarious cultural-civilizational, linguistic, demographic, economic or political influences flowing from differentiated attitudes to life and obligatory social values represented within this area (Chlebowczyk 1975: 24). In contemporary Polish sociological thought on borderland areas, the following aspects are accentuated ${ }^{2}$ : (1) location in space (relation to territory, more often than not close to the state border); (2)

2 Regardless of the difference in terminology between "social borderland" versus "transborderland" (cf. Z. Kurcz and A. Sadowski). 
contacts between representatives of various ethnic groupings, and actions connected to these contacts, oriented to ethnic Others; as well as the social and institutional results of these actions in the form of a border-transgressing community; and (3), in relation to the latter: common identity and common aims and interests, institutions and social organizations (cf. Gołdyka et al. 1997: 7-8; Kurcz 2008, 2009: 9-10; Sadowski 1995, 2014: 111; for more on the Polish conceptions, see Gołdyka 2013). Such a situation leads human existence in borderlands to have "its own dynamics that follows from spatial vicinity, directness and easiness of contacts with another society, with a different culture [...]" (Szlachcicowa 1999: 72). In connection with it, "various visions of reality referring to various, alternative religious, ideological (i.e. national) and common systems" interrelate here (Wojakowski 2005: 41).

One can speak about the development of a specific social situation in borderlands: a national neighbourhood (Dolińska 2013), within the frames of which direct contacts influence the way ethnically different people are perceived. ${ }^{3}$ This is not only because it is much easier to notice this dissimilarity (even if looked at superficially), but it is also about the fact that creating social boundaries in an ethnic dimension is individualized, and dividing the social world between "Insiders" and "Strangers" proceeds according to differentiated rules taken by particular persons: borderland "makes a general social consensus as for the group boundaries more complicated" (Wojakowski 2005: 41). It directly influences employing differentiated criteria for separating the "Strangers." At one's disposal are two of them: an a posteriori criterion, based on individual experiences, observations, and contact with ethnically "Others"; and an a priori one, featuring, among others, stereotypes (Kozera 1999: 43). One may, however, assume that in a situation of systematic contact with an ethnically different neighbour, the first of these criteria will be made use of more often by the inhabitants of a borderland than by the inhabitants of geographic areas that do not experience a direct territorial adjacency with different states/nations.

The aforementioned lack of consensus as to establishing boundary groups and using different criteria for separating both "Strangers" and "Others", especially in a situation of a ethnic dissimilarities, is reflected in the employment of different strategies of

'coping with the other side of the border'. We have to do either with the strategy of contact with the 'familiar strangeness', national strangeness or religious strangeness which we have been familiar with for ages and which is thus more predictable for us in the future, or [with the strategy of] contact with the 'familiar otherness', when people, institutions, communities on the other side of the border are somewhat different from us yet mean something for us. (Kurczewska 2005: 379)

3 David Newman and Anssi Paasi suggest that broadly understood borders (including social boundaries) be analyzed on various spatial scales, e.g. in the borderland, in a local context, and in everyday practice (Newman and Paasi 1998). The issue of national relations has already been taken up many times in borderlands studies (e.g. Donnan and Wilson 1999; Wastl-Walter 2011). This article, whose aim is to investigate the Polish-German neighbourhood in divided towns, thus refers to these reflections. 


\section{The Polish-German borderland}

The function of the Polish-German border has changed in different historical periods. Stanisław Ciok (1992: 13-18) divides the post-war period into five stages. In the first (from 1945 to 1950, completed with the signing by the German Democratic Republic and the Polish People's Republic of the Treaty of Zgorzelec, wherein the border decisions made at Potsdam were ratified), the border was hermetic, played the barrier function - moving about the border zone was then limited and subject to control, and the border districts ${ }^{4}$ were dedicated to military settlement). This stage, however, still featured some past economic ties or those forced by commune infrastructure shortages on the two sides (for the border line marked in 1945 crossed the commune infrastructure and cut through economic regions). While completing the image of the border as a barrier it is noteworthy to mention about hostile relations between Poles and Germans, which is undoubtedly an aftermath of the events of World War II and soon afterwards - attitudes that were enhanced by the propaganda of the Polish People's Republic depicting Germans as revisionists who threatened Poland (after GDR came into being, the image of "hostile Germans" referred to Western Germans only) (Opiłowska 2010: 111-112, 2015a: 204-205).

The second phase encompassed the next decade (the 1950s) when the border was still impermeable and its crossing was formalized, which can be connected with the situation in both countries (the events of 1953 in GDR and of 1956 in Poland). Simultaneously, in this period, as described by Elżbieta Opiłowska (2015a: 205-206), in the official discourse the border was referred to as "the border of friendship and peace", thus reflecting the kind of relations between these states, which were bound by "socialist friendship", and the meetings practiced by their authorities.

The next stage includes the 1960s (anticipated by limited possibilities to cross the border as early as after the thaw of 1956). In the border region certain limitations - administrative, military and those affecting people's mobility - were done away with. This led to intensification of institutional and private contacts. Polish women tended to be employed in Germany within the regime of local border traffic.

In the fourth stage (1972-1980), contacts between Poles and Germans (at various levels, including the informal) were the most intensive and common, especially in the borderland but also in the sphere of interstate relations. The border was opened on 1 January 1972 from this day on it was possible to cross within a visa-free and passportless regime, and customs and foreign currency limitations were abandoned, as well. After some time, however, the GDR authorities restored customs controls. The decision to close down the border was made by the GDR authorities in 1980 due to both the growing importance of the "Solidarity" (Polish: Solidarność) trade union and the anxiety that its activity would influence German society, and also for economic reasons (Opiłowska 2009: 227).

The last phase enumerated by Ciok started in 1980 when the border began to again fulfil the barrier function. Mass tourist movement was stopped and institutional linkages limited; eventually, contacts became frozen during the Martial Law period.

4 By the term "district" we mean the mid-level of the administrative division (between "commune" and "province") in the contemporary (and of that time) Poland; powiat in Polish. 
Julita Makaro adds a sixth element to Ciok's periodization, starting in the 1990s when the border opened once more. The author points at the growth of cooperation, the emergence of Euroregions, the border losing its hitherto existing function and becoming deformalized it became easy to cross and no longer had a barrier function (Makaro 2007: 28).

The next turning point was Poland's accession to the European Union, and from this time on it has been possible to isolate a next - seventh - stage, completed with Poland's joining the Schengen Treaty in 2007, and the doing away with restrictions for Poles in the German labour market in 2011 (Dolińska, Makaro and Niedźwiecka-Iwańczak 2016: 366). Elżbieta Opiłowska, in describing the last two stages of the transformation of the Polish-German border, even writes about the "vanishing frontier"5 (Opiłowska 2015a: 208-210).

While trying to outline the evolution of social contacts in the twin towns in this study (Zgorzelec/Görlitz, Gubin/Guben, Słubice/Frankfurt-Oder), one may make use of the proposal by Andrzej Sadowski which treats their development on the frontier townborderland town axis (1996: 7-9). The typical frontier town is located in the vicinity of an impermeable border, is peripheral, and has neither any impact on the neighbour nor experiences its influence. A borderland town, in turn, becomes a local centre ${ }^{6}$ and within its space a clash of cultures takes place - systems of values, conditions and ways of life - at the instance of systematic and persistent contacts between the inhabitants of the town and its counterpart on the other side of the border. A scheme to describe the process of divided towns shifting from frontier towns into borderland towns is presented in Table 1.

And so the transformation of a twin town into a borderland town can be defined in the following way:

we can speak of it when social relations in a divided town dominate over the institutional ones or are at least equally intensive, and it may come into being only in the conditions of full unconstraint and freedom as for their creation. A particular type of social relations in this scheme follows from the fact that they are of personal character, directed autotelically, take place in the private sphere and are not subject to systemic limitations external to an individual. (Dolińska, Makaro and Niedźwiecka-Iwańczak 2016: 368)

5 The same title was given to a book edited by Agnieszka Łada and Justyna Segeš-Frelak (2012), devoted to a "new" Polish migration to Germany that has taken place in Mecklenburg-Vorpommern, in the border areas. Interestingly, some of the people engaged in this process share the professional and family spheres of life between the two countries, which makes this migration temporary.

6 We made an attempt to diagnose the situation in Zgorzelec and Gubin with respect to this in Dolińska, Niedźwiecka-Iwańczak (2015). 
Table 1: Stages of development of divided towns, with characteristics of social contacts

\begin{tabular}{|c|c|c|c|c|c|c|c|c|c|c|c|c|}
\hline & & 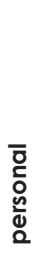 & $\begin{array}{l}\overline{\bar{\sigma}} \\
\frac{\bar{\sigma}}{\bar{\sigma}} \\
\varepsilon\end{array}$ & 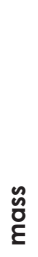 & ఏ్ర & $\begin{array}{l}\frac{u}{0} \\
\frac{0}{0} \\
\frac{5}{0}\end{array}$ & 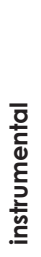 & 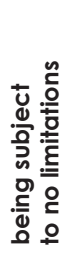 & 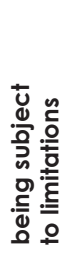 & $\begin{array}{l}0 \\
\frac{0}{0} \\
\frac{0}{0} \\
0 \\
\frac{0}{0} \\
\stackrel{ \pm}{0} \\
0 \\
\pm \\
.0\end{array}$ & 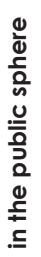 & \\
\hline $\begin{array}{l}\text { frontier } \\
\text { town }\end{array}$ & stage I & & $x$ & & $x$ & & $x$ & & $x$ & $x$ & $x$ & \multirow{5}{*}{$\begin{array}{l}\text { FASCADE } \\
\text { STAGE }\end{array}$} \\
\hline \multirow{5}{*}{$\downarrow$} & stage II & & $x$ & & $x$ & & $x$ & & $x$ & & $x$ & \\
\hline & stage III & $x$ & $x$ & & $x$ & & $x$ & & $x$ & $x$ & $x$ & \\
\hline & stage IV & $x$ & $x$ & $x$ & & $x$ & $x$ & $x$ & & $x$ & $x$ & \\
\hline & stage $V$ & & & & $x$ & & $x$ & & $x$ & & & \\
\hline & stage VI & $x$ & $x$ & $x$ & & $x$ & $x$ & $x$ & & $x$ & $x$ & $\begin{array}{l}\text { INSTITUTIONAL } \\
\text { STAGE }\end{array}$ \\
\hline $\begin{array}{l}\text { borderland } \\
\text { town }\end{array}$ & stage VII & $x$ & $x$ & $x$ & & $x$ & $x$ & $x$ & & $x$ & $x$ & SOCIAL STAGE \\
\hline
\end{tabular}

Source: Dolińska, Makaro and Niedźwiecka-Iwańczak (2016: 368)

\section{Methodological background}

Theoretical assumptions on familiarity and strangeness (including social distance) and the significance of these categories for analyzing social relations in the borderland enable the formulation of the research questions which have guided the empirical analysis presented in the sections below. Our research questions are:

1) How do the inhabitants of the Polish parts of the divided towns of Zgorzelec/Görlitz, Gubin/Guben, and Słubice/Frankfurt (Oder) perceive their German neighbours living "just across the river"? What features do they ascribe to them? To what extent does their image include general and detailed features? What kind of emotional approach do they have to these neighbours? To what extent are they open to them (on the level of practice and declarations), and in what roles (at the personal and material levels)?

2) How do the same Polish inhabitants perceive "the world on the other side of the river", constituting the material surroundings in which the German neighbours live? What advantages and disadvantages do they perceive in Görlitz, Guben and Frankfurt (Oder)? Do they declare a possibility to come and live in the German part of the twin towns?

The empirical basis of this inquiry lies in the results of research carried out in three projects: (1) "Borderland Location of Zgorzelec in the Opinions of its Residents" (2010), (2) "Borderland Location of Gubin in the Opinions of its Residents" (2012) and (3) "Borderland Location of Stubice in the Opinions of its Residents" (2015), which show how these towns' 
residents perceive their borderland location. ${ }^{7}$ The same methodology was used in all of them: the method of schedule-structured interviews, with random and representative samples of respondents. ${ }^{8}$

The findings presented here constitute only a small part of the results obtained in the course of the research projects, being limited to an inquiry into the opinions of the inhabitants of the borderland locations of Zgorzelec, Gubin and Stubice. In total, the research included the following issues: transborder activity and factors underlying it; sense of safety; evaluation of neighbourly relations; characteristics of the German neighbours (including stereotypes) and emotional approaches to them; evaluation of the town's borderland location (quality of life, tourist attractiveness associated with it); and evaluation of the institutional steps taken in the twin towns, including perception of priorities with regard to cooperation on this level. The questionnaire that made it possible to tackle these topics comprised of 49 questions of various levels of standardization (on average, it took 45 minutes to accomplish one interview) $)^{9}$. We would like to underline that a part of the research has already been reported in a series of articles, and the findings summing up the project will be published in a monograph titled The Miracle of Borderland?

\section{Transborder activities}

It is common for the inhabitants of Zgorzelec, Gubin and Stubice to cross the border and head for the German parts of the divided towns (ca. $80 \%$ in the first and second case, and $90 \%$ in the third). The most frequent activities are shopping and walking. A bit more than a half of the inhabitants of Zgorzelec make use of the cultural offerings in Görlitz, and $40 \%$ of those of Stubice and Gubin meet with German acquaintances (this goal is realized by a fourth of the inhabitants of Zgorzelec). The reasons for crossing the border are presented in detail in Graph 1.

As for the frequency of particular transborder activities, it should be underlined that more than half of respondents cross the border to take walks (in all three towns), and to do shopping often (answers in Gubin and Słubice), i.e. at least once a week, for these are the activities that are written into everyday practices (Dolińska, Makaro and Niedźwiecka-Iwańczak 2014: 40). Additionally, it should also be underlined that in each of the towns a bit less than half of

7 The research was conducted by researchers in the Department of Sociology of Borderland, Institute of Sociology, University of Wrocław. The Polish names of the projects are: Pograniczne położenie Zgorzelca w opiniach jego mieszkańców, Pograniczne położenie Gubina w opiniach jego mieszkańców and Pograniczne położenie Stubic w opiniach jego mieszkańców.

8 The sizes of the samples were set with the significance level of 0.05 and evaluation error of no more than $5 \%$. The samples included 382 persons in Zgorzelec, 376 in Gubin and the same in Słubice. Eventually the analyses were conducted on, respectively, 372, 374 and 365 interviews, which slightly increased the level of significance error: in Zgorzelec it was $5.07 \%, 5.01 \%$ in Gubin and $5.1 \%$ in Słubice. A random sample was taken from databases of the Regional Statistical Offices (in Wrocław for Zgorzelec, and in Zielona Góra for Gubin and Słubice).

9 Due to formal limitations, it is not possible to include the research tool. We refer to the questions in their original form in appropriate sections of the article. 
respondents (out of those who practice this activity in general) meet German acquaintances at least once a week (from $12 \%$ in Zgorzelec up to $17.5 \%$ in Słubice).

Graph 1: Reasons for Poles crossing the border

to make use of the offer of the German travel agencies

to realize common projects with German partners

to set out on travels into German from there

to participate in religious holidays

to participate in family occasions of German friends

to meetGerman friends/acquaintances

to meet German boy/girlfriend, partner

to go to the disco

to benefit from the offer of cultural institutions (museum, theatre,

to do sport

to make use of services (e.g. hairdresser, restaurant, cafè, pub)

to benefit from the offer of educational institutions (schools,

to go for a walk

to go shopping

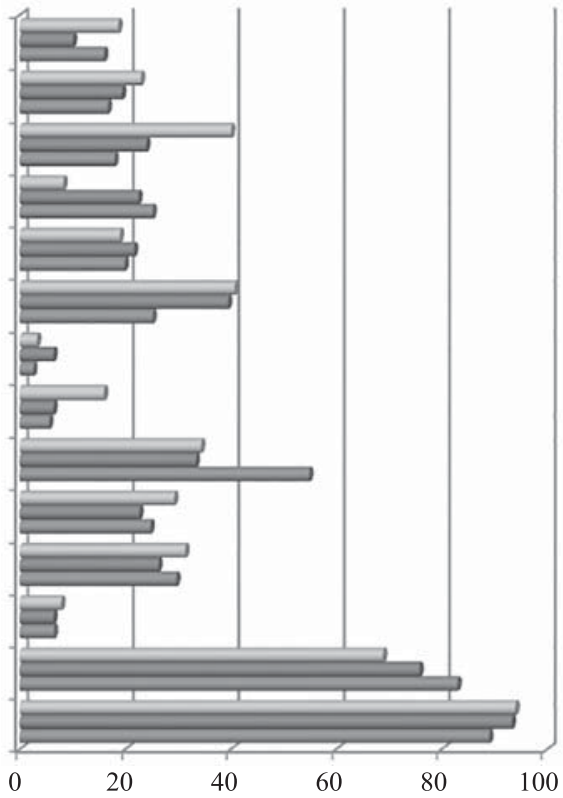

Frankfurt

Guben

Görlitz

Germans also cross the border - our respondents notice the presence of their German neighbours around the towns under investigation. ${ }^{10}$ In all of them, one can observe dominant indicators of two pragmatic aims - shopping, making use of services, and one activity going beyond the pragmatic dimension: walking. However, the respondents perceive that autotelic goals are also practiced quite commonly. One remark should be made here, though - in the view of respondents, Germans more often accomplish various aims on the Polish side of the twin town than the respondents themselves do on the German side (taking into account declarations of visits they make to German neighbours with a particular aim).

10 Germans' transborder practices can only be inferred - from the utterances by the inhabitants of Zgorzelec, Gubin and Stubice who sometimes see their neighbours from across the river on the Polish side. The answers are based on the observations made by respondents in the public sphere but also on their own experiences - contacts and meetings. One can argue that it is hardly possible to infer the frequency of the activities taken by the German inhabitants of the divided towns, yet these circumstances reflect to some extent the real state of affairs (even though respondents might have overestimated the mass character of the German presence in the towns). For more on the transborder activities of inhabitants in territorial units of a higher level (the districts of Zgorzelec and Görlitz), see Knippschild and Schmotz (2015: 103-104). 
The ongoing process - transformation of twin towns into borderland towns ${ }^{11}$ - is testified to by: mass border crossing; accomplishment of a differentiated range of transborder activities on the neighbour's side (although it is the activities of an instrumental and instrumental-autotelic character that prevail here, the activities of an autotelic nature are maintained as well ${ }^{12}$, and they are not incidental); locating activities in the public sphere but also in the private sphere (though smaller in number); maintaining contacts of a personal and material character, yet with dominance of the latter (cf. Dolińska, Makaro and NiedźwieckaIwańczak 2016).

\section{Perception of German neighbours}

Transborder activity can undoubtedly be connected with the opinions of the inhabitants of the Polish divided towns on the German neighbours living right across the river. What are, then, the closest (as for spatial-demographic criteria) Germans like? Our respondents did not find it difficult to describe their neighbours ${ }^{13}: 88.2 \%$ of the inhabitants of Zgorzelec generated 925 answers in which 189 features were mentioned (the remaining $8 \%$ answered "I don't know", whereas $3.8 \%$ declared "people were different"); $91.2 \%$ of the inhabitants of Gubin generated 867 answers including 204 features (the remaining $8.8 \%$ answered "I don't know"); $90 \%$ of the inhabitants of Słubice generated 883 answers referring to 167 features (the remaining $10 \%$ said "I don't know"). ${ }^{14}$ Specification of the features mentioned most often (indicated at least 10 times) is presented in the table below.

An analysis of the data obtained in all the towns under investigation makes possible the claim that among the features most frequently mentioned are those that describe Germans stereotypically and refer particularly to, firstly, their behaviour in relation to others (on the one hand, well-mannered, nice, pleasant, mannerly, kind-hearted, polite, helpful, calm, nice/pleasant, peaceful, peaceable; on the other hand, swaggering, noisy and loud), and, secondly, their attachment to order, broadly understood (hence mainly caring for cleanness and tidiness; observing regulations; and being self-disciplined, well-organized, punctual, and

11 This process supports acquiring linguistic competence by the inhabitants of the borderland. $15 \%$ of the inhabitants of Zgorzelec, $12.8 \%$ of Gubin and $20.3 \%$ of Stubice referred to their fluent knowledge of German; about one third of respondents in all three towns declared that they were able to understand their foreign neighbours but as for answering they could manage only simple questions; and $35 \%$ of the inhabitants of Zgorzelec, $36.6 \%$ of Gubin and $35.5 \%$ of Słubice know only some German words and expressions. $18 \%$ of the inhabitants of Zgorzelec, $16 \%$ of Gubin and $14 \%$ of Słubice do not know any German.

12 For more on the qualification of particular practices, see Dolińska, Makaro and NiedźwieckaIwańczak (2013).

13 The examined were asked: "Please, enumerate three features of the neighbours living in Görlitz/ Guben/Franfurt" (open-ended question). In the course of the research it was also the stereotype of a German that was analysed, by means of a closed-ended question - cf. Dębicki and Doliński (2010); Dębicki and Makaro (2017); Dębicki and Doliński in the present volume.

14 And the answer "I don't know" covered only $4.5 \%$ of all indications in Zgorzelec (with n=969), $3.6 \%$ in Gubin (with $n=900$ ), and $4 \%$ in Słubice (with $n=920$ ). 
hard-working). The remaining features, appearing definitely less often, refer to Germans' material affluence (thrifty, rich) and physical appearance; the latter were most strongly articulated in Stubice. Marginally, and only in Zgorzelec, are references made to the negative historical experiences from the times of WWII.

Table 2: Features of German neighbours

\begin{tabular}{|c|c|c|c|c|c|c|c|c|c|}
\hline No. & Zgorzelec $(n=925)$ & 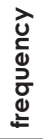 & 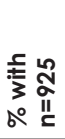 & Gubin (n=867) & 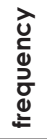 & 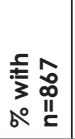 & Słubice $(n=883)$ & $\begin{array}{l}\widehat{U} \\
\stackrel{c}{0} \\
\stackrel{\partial}{0} \\
\stackrel{d}{=}\end{array}$ & 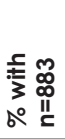 \\
\hline 1 & well-mannered & 75 & 8.1 & $\begin{array}{l}\text { careful of cleanness, } \\
\text { tidiness }\end{array}$ & 96 & 11.1 & well-mannered & 58 & 6.6 \\
\hline 2 & $\begin{array}{l}\text { careful of } \\
\text { cleanness, tidiness }\end{array}$ & 70 & 7.6 & well-mannered & 65 & 7.5 & noisy, loud & 47 & 5.3 \\
\hline 3 & $\begin{array}{l}\text { observes } \\
\text { regulations }\end{array}$ & 44 & 4.8 & nice, pleasant & 47 & 5.4 & nice, pleasant & 37 & 4.2 \\
\hline 4 & swaggering & 43 & 4.6 & polite & 41 & 4.7 & mannerly & 34 & 3.9 \\
\hline \multirow{2}{*}{5} & mannerly & 34 & 3.7 & \multirow{2}{*}{ mannerly } & \multirow{2}{*}{33} & \multirow{2}{*}{3.8} & \multirow{2}{*}{$\begin{array}{l}\text { careful of } \\
\text { cleanness, tidiness }\end{array}$} & \multirow{2}{*}{32} & \multirow{2}{*}{3.6} \\
\hline & kind-hearted & 34 & 3.7 & & & & & & \\
\hline \multirow{2}{*}{6} & \multirow{2}{*}{ noisy, loud } & \multirow{2}{*}{32} & \multirow{2}{*}{3.5} & \multirow{2}{*}{ calm } & \multirow{2}{*}{28} & \multirow{2}{*}{3.2} & kind-hearted & 31 & 3.5 \\
\hline & & & & & & & helpful & 31 & 3.5 \\
\hline \multirow{2}{*}{7} & \multirow{2}{*}{ polite } & \multirow{2}{*}{31} & \multirow{2}{*}{3.4} & kind-hearted & 26 & 3 & \multirow{2}{*}{ polite } & \multirow{2}{*}{30} & \multirow{2}{*}{3.4} \\
\hline & & & & friendly, amicable & 26 & 3 & & & \\
\hline 8 & calm & 29 & 3.1 & helpful & 24 & 2.8 & swaggering & 24 & 2.7 \\
\hline 9 & self-disciplined & 25 & 2.7 & observes regulations & 23 & 2.7 & $\begin{array}{l}\text { ugly, fat, tasteless, } \\
\text { badly-dressed }\end{array}$ & 23 & 2.6 \\
\hline 10 & helpful & 24 & 2.6 & punctual & 22 & 2.5 & friendly, amicable & 22 & 2.5 \\
\hline 11 & thrifty & 20 & 2.2 & \multirow{2}{*}{ nice, pleasant } & \multirow{2}{*}{21} & \multirow{2}{*}{2.4} & $\begin{array}{l}\text { observes } \\
\text { regulations }\end{array}$ & 18 & 2 \\
\hline 12 & punctual & 19 & 2.1 & & & & $\begin{array}{l}\text { peaceful, } \\
\text { peaceable }\end{array}$ & 18 & 2 \\
\hline \multirow[b]{2}{*}{13} & \multirow[b]{2}{*}{ friendly, amicable } & \multirow[b]{2}{*}{18} & \multirow[b]{2}{*}{1.9} & \multirow[b]{2}{*}{ hard-working } & \multirow[b]{2}{*}{18} & & rich & 14 & 1.6 \\
\hline & & & & & & 2.1 & $\begin{array}{l}\text { smiling, cheerful, } \\
\text { merry }\end{array}$ & 14 & 1.6 \\
\hline & & & & swaggering & 16 & 1.8 & calm & 13 & 1.5 \\
\hline 14 & sen-ussuteu & 17 & 1.0 & self-disciplined & 16 & 1.8 & hard-working & 13 & 1.5 \\
\hline 15 & rich & 16 & 1.7 & naing & & & & & \\
\hline 10 & hard-working & 16 & 1.7 & MUsy & 10 & 1.0 & 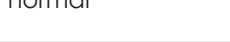 & 10 & 1.1 \\
\hline & & & & honest & 10 & 1.2 & & & \\
\hline & ni & & & outgoing & 10 & 1.2 & & & \\
\hline & & & & peaceful & 10 & 1.2 & & & \\
\hline & & & & thrifty & 10 & 1.2 & & & \\
\hline 17 & hospitable & 11 & 1.2 & - & & - & - & & - \\
\hline 18 & accurate & 10 & 1.1 & - & & - & - & & - \\
\hline
\end{tabular}


The image of the German neighbour that emerges from our research is nuanced in each of the towns under inquiry: the characteristics brought up by respondents are differentiated and partly also unrepeated, "unstereotypical". Other than the features indicated most frequently (see Table 2), constituting 10-11\% of all mentioned in Zgorzelec (with n=189), Gubin (with $\mathrm{n}=204$ ) and Słubice (with $\mathrm{n}=167),{ }^{15}$ there were numerous individual indications. And so, for instance, a respondent in Zgorzelec relates: "they don't throw themselves at your head, [they are] inventive, don't become intimate with others, ordinary, behave strange in shops because they want to jump the queue, aren't engaged with the inhabitants of Zgorzelec in common life"; in Gubin: "it's not a problem for them to ask for help, modest, [they] would always be eating, smart, are eager to haggle, park cars chaotically"; in Słubice: "decent, are not interested in their neighbour's private life, aren't provocative, [are] irritating, like boasting, thrust their lifestyle upon you". Thus one can say that the image of the German neighbour is composed, similarly to the "syndrome of stereotypical perception of Germans" (Błuszkowski 2005: 51-54), of rich content and complex inner structure as it refers to various generally categorized properties (see more below).

\begin{abstract}
When comparing the data obtained in our research with studies carried out by the Instytut Spraw Publicznych [Institute of Public Affairs - IPA], which periodically conducts research on a nation-wide sample of Poles, it needs to be underlined that in the borderland one can hardly observe the issues connected with three areas of interest: firstly, with history (which was mentioned by $25 \%$ of Poles in 2013, and by $21 \%$ in 2016 in the aforementioned research by IPA); only in Zgorzelec were the negative historical experiences from the time of WWII marginally referred to (by $2 \%$ of respondents); secondly, with regard to politics and political relations (these, in turn, were referred to by $5 \%$ of Poles in the 2013 IPA research and by $12 \%$ in 2016); and thirdly, with the labour market ( $6 \%$ of Poles in 2013 and $7 \%$ in 2016). Moreover, in the borderland we do not observe any references to general associations like "the western neighbour" or "the West" (whereas these were mentioned by $20 \%$ of Poles in 2013 and $22 \%$ in 2016). (Lada 2016: 5-6)
\end{abstract}

In the case of the last of these categories, it needs to be underlined that territorial vicinity favours specifying the neighbour's image, and so the fact that the inhabitants of the borderlands do not make generalized associations should not be surprising. Yet as for the labour market, it is perceived by respondents rather as a component of "the standard of life in Germany", recalled as an advantage of living on the other side of the Nysa or Odra rivers (see more below), than as an association with Germans as such. This circumstance, accompanied by the fact that almost $41 \%$ of the inhabitants of Zgorzelec, $53 \%$ of Gubin and $48 \%$ of Słubice like their spatially closest German neighbours, whereas antipathy is reported by only $3-3.8 \%$ of respondents ${ }^{16}$ (in the remaining case respondents declared indifference -

15 A the same time, the features mentioned the most frequently constituted $63 \%$ out of all indications in Zgorzelec (581 with $\mathrm{n}=925$ ) and $64 \%$ in Gubin ( 555 with $\mathrm{n}=867$ ), whereas in Stubice it was 52.5 $\%$ (469 with $\mathrm{n}=883$ ).

16 The level of antipathy expressed by Poles as a whole towards Germans is definitely (at least three times) higher (Lada 2016: 22). 
respectively, $54.6 \%, 42.2 \%$ and $47.7 \%{ }^{17}$ ), allows one to infer about the premises for treating these neighbours as "Others" and not "Strangers".

The predominantly positive characteristics of Germans living on the other bank of the river Nysa Łużycka/Odra Rivers, as well as the lack of antipathy towards them revealed in declarations, needs to be juxtaposed with some other relevant indicators in order to answer the question of who the inhabitants of Görlitz, Guben and Frankfurt are for the Polish respondents. One of the indicators is surely the social distance measured in the level of openness to German neighbours fulfilling certain social roles in the closest vicinity of the inhabitants of Zgorzelec, Gubin and Słubice ${ }^{18}$. It cannot be overlooked that in all Polish parts of the twin towns under study Germans are most welcomed as tourists (by $85-86 \%$ of respondents ${ }^{19}$ ) and customers (79-86\%), yet what attracts our attention is the inclusion of them into the group of close persons, mainly neighbours (66-68 \% of respondents would welcome Germans in this role) and friends (57-62\%), as well as partners in professional life (56-61\%). Declarations of this sort disclose the consequences of a gradual opening (bearing in mind the historical context) towards "ethnically Others" living in closest proximity, not only due to economic (instrumental) profits obtained but also to those benefits of a strictly social character, connected with the strengthening of bonds and co-creating primordial groups. It is not yet so in every case, as a slightly lower level of acceptance is given to Germans as family members (42-46 \%), i.e. "the closest of closest", and partners (40-46\%), who are less approved of in the sphere of professional collaboration than cooperators. Germans are least welcome as subordinates (31\%) and superiors (23-24\%). While explaining this distance, articulated in the sphere of professional dependency, it needs to be pointed out that being in such a relation that can be associated with partial loss of autonomy may generate conflicts whose sources are in both cultures: the question of professional and social competences, the style of work desired in the perspective of efficiency, and/or interpersonal relations.

\section{Perception of "the world across the river"}

The last two indicators that permit us to determine who the German neighbour is for the inhabitants of Zgorzelec, Gubin and Słubice are constituted by, firstly, a declaration regarding the possibility of settling down in the German part of the twin towns (with the economic arguments and those concerning the living standard being omitted), and,

17 The examined were asked, "What is your attitude to the residents of Görlitz/Guben/Frankfurt?" Possible answers were: [1] I like them very much, [2] I like them, [3] They are indifferent to me, [4] I do not like them, [5] I definitely do not like them, [6] I do not know.

18 The interviewees were asked: "In what role would you see Germans in your surroundings?" (tourists, superiors, subordinates, collaborators, clients, friends, neighbours, partners, family members): [1] definitely, [2] willingly/rather willingly, [3] neither willingly nor reluctantly, [4] rather reluctantly, [5] definitely reluctantly.

19 The data refer to the recoded variable: "willingly" as a combination of the answers "definitely willingly" and "rather willingly". 
secondly, perceptions of the advantages and disadvantages of living on the other side of the border. It should be noted that approximately half of respondents $(47-50 \%)$ would move to the neighbouring town - rather on a permanent basis (70-80\% of them) than temporarily ${ }^{20}$. This answer seems to be consistent with the fact that they perceive the German parts of the twin towns definitely more in terms of advantages than disadvantages.

The triad of the most important advantages ascribed to each of the towns is composed of: (1) developed infrastructure, (2) cleanness, tidiness and beauty, and (3) the high standard of living in Germany. The category "developed infrastructure" includes answers referring to housing resources - accessibility, higher standards, lower prices, conditions of public transportation and roads, leisure activities and facilities (including attractions for various age groups), educational institutions (schools, kindergartens), the healthcare system, public spaces (parks, monuments), shopping and cultural facilities. The second of the categories includes answers concentrating on cleanliness, tidiness, beauty of the town and its particular objects, as well as the fact that they are well maintained (for instance: "Germans take greater care of everything"). Finally, as for the category "living standards in Germany", this includes indications of higher wages and old age pensions, better social care (various types of benefits and support for different categories of persons), high living standards, a lower unemployment rate/labour accessibility, welfare and wealth, all of which are connected by respondents with the situation in the German Federal Republic, with the life conditions in frontier towns as its manifestation. The order (reflecting the frequency of the appearance of particular answers) in Görlitz, Guben and Frankfurt is different (see table below), which can be linked to the local conditions (cf. Dolińska and Niedźwiecka 2015; Dolińska and Niedźwiecka-Iwańczak 2014: 203; NiedźwieckaIwańczak 2011: 64-68). The three most frequently mentioned advantages cover over $80 \%$ of answers in all cases.

While enumerating the advantages of the German parts of the divided towns, some respondents referred also to German neighbours' features - they tended to be described as nice and kind-hearted, pleasant, well-mannered Germans who "are able to organize and cooperate". It was also underlined that Germans are clean and tidy and in neighbourly relations "everyone lives their own life". Sometimes the "mentality different than the one in Poland" was perceived as an advantage. were of a bit higher standard and cost as much as in Zgorzelec/Gubin/Słubice?": [1] yes, but only temporarily, [2] yes, for a longer run, [3] no, [4] it's hard to say. 
Table 3: Advantages of Görlitz, Guben and Frankfurt-Oder ${ }^{21}$

\begin{tabular}{|c|c|c|c|c|c|c|c|c|}
\hline Görlitz & 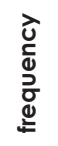 & 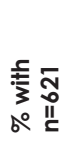 & Guben & 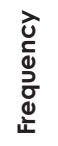 & 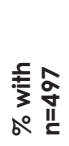 & Frankfurt 588 & 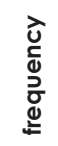 & 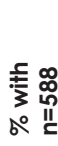 \\
\hline town infrastructure & 214 & 34.5 & $\begin{array}{l}\text { living standard in } \\
\text { Germany }\end{array}$ & 161 & 32.4 & $\begin{array}{l}\text { living standard in } \\
\text { Germany }\end{array}$ & 269 & 45.7 \\
\hline cleanness, beauty & 194 & 31.2 & town infrastructure & 123 & 24.8 & town infrastructure & 213 & 36.2 \\
\hline $\begin{array}{l}\text { higher living } \\
\text { standard in } \\
\text { Germany }\end{array}$ & 123 & 19.8 & $\begin{array}{l}\text { cleanness and } \\
\text { beauty }\end{array}$ & 119 & 24 & $\begin{array}{l}\text { cleanness and } \\
\text { beauty }\end{array}$ & 59 & 10 \\
\hline safely/calmly & 53 & 8.5 & $\begin{array}{l}\text { people and their } \\
\text { features }\end{array}$ & 58 & 11.7 & $\begin{array}{l}\text { people and their } \\
\text { features }\end{array}$ & 24 & 4.1 \\
\hline $\begin{array}{l}\text { people and their } \\
\text { features }\end{array}$ & 33 & 5.3 & safely/calmly & 33 & 6.7 & big/bigger city & 23 & 4 \\
\hline other & 4 & 0.6 & other & 2 & 0.4 & other & 0 & 0 \\
\hline total & 621 & 100 & total & 497 & 100 & total & 588 & 100 \\
\hline
\end{tabular}

As for the human factor, it dominates among the disadvantages mentioned in Zgorzelec and Gubin (one third of all the answers), whereas in Stubice it was the second most frequent (one fifth of all the disadvantages mentioned). This category includes answers featuring Germans' attributes, presenting the image of social relations, showing the neighbours' approach to Poles and their own approach to Germans, as well as expressing the feeling that Germany is a strange country and that a man would feel ill at ease there. This means that loud and noisy, unpleasant, cunning, indifferent, and cold inhabitants are spoken of as disadvantageous features of the towns across the Odra and Nysa Rivers. A part of respondents paid attention to Germans' negative, unfriendly approach to Poles, for example: "they do not respect Poles", "Poles living in blocks of flat are treated as intruders", which is also expressed in the activities by neo-Nazi organizations in frontier towns. The stereotype of a Pole as a thief was also mentioned. Additionally, respondents tended to speak about "feeling shame due to stereotypes - of an alcoholic or a lazy man". They also brought up cultural differences, ${ }^{22}$ different customs which manifest themselves, for example, in attitudes to regulations, in observing rules and executing them from others: they point at "exaggerated order" and "excessive law observance" among the Germans, and they claim that "people

21 The interviewees were asked, "What are, in your opinion, advantages of living in Görlitz/Guben/ Frankfurt? Please, enumerate maximum three advantages" (open-ended question). General categories isolated in the table were not suggested by the researchers but generated in the course of multiple readings of the answers by the members of the research team. The procedure of triangulation employed by the investigators (Denzin 2009: 301, 303) made it possible to increase the reliability and validity of this categorization.

22 Cultural differences experienced in bi-national, Polish-German marriages are subject to analysis by Emilia Jaroszyńska (2015). 
supervise one another, you are not allowed to behave louder at your own place, nark at one another". The observations made by the inhabitants of the Polish towns of the western borderland can be interpreted according to the insights about cultural distance offered by intercultural psychologists - in the light of their analyses, Poles and Germans differ as to the degree of uncertainty avoidance (low and high) (Uncertainty Avoidance Index), which is connected to a person's approach to the future and orientation to a shorter or longer time horizon. The high level of uncertainty avoidance that characterizes Germans, together with a long-term orientation, tend to manifest in taking care of order, tidiness, and having clear rules that are respected in everyday life (Boski 2010: 135, 148-149). Our respondents are not in favour of the type of neighbourly relations connected with Germans' coldness and indifference, either: "lack of help, neighbourly loyalty and solidarity from the neighbours", the fact that they "don't visit one another, aren't in touch with the neighbours". Hence, some interviewees underlined that they would feel strange in Germany and that "it was better to live in Poland, at home".

Table 4: Disadvantages of Görlitz, Guben and Frankfurt-Oder ${ }^{23}$

\begin{tabular}{|c|c|c|c|c|c|c|c|c|}
\hline Görlitz & 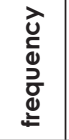 & 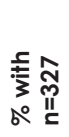 & Guben & 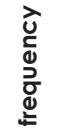 & 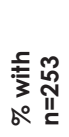 & Frankfurt & 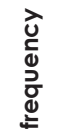 & 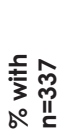 \\
\hline human factor & 115 & 35.2 & human factor & 78 & 30.8 & $\begin{array}{l}\text { high prices, costs of } \\
\text { living }\end{array}$ & 109 & 32.3 \\
\hline $\begin{array}{l}\text { high prices, costs of } \\
\text { living }\end{array}$ & 87 & 26.6 & $\begin{array}{l}\text { high prices, costs of } \\
\text { living }\end{array}$ & 49 & 19.4 & human factor & 87 & 25.8 \\
\hline $\begin{array}{l}\text { desolate town, } \\
\text { ageing population } \\
\text { (young people } \\
\text { have left) }\end{array}$ & 54 & 16.5 & $\begin{array}{l}\text { no/few jobs/ } \\
\text { companies }\end{array}$ & 39 & 15.4 & $\begin{array}{l}\text { desolate town, } \\
\text { ageing population } \\
\text { (young people have } \\
\text { left) }\end{array}$ & 35 & 10.4 \\
\hline $\begin{array}{l}\text { requirement to } \\
\text { know German/ } \\
\text { linguistic barrier/ } \\
\text { incompetence }\end{array}$ & 45 & 13.8 & $\begin{array}{l}\text { requirement to } \\
\text { know German/ } \\
\text { linguistic barrier/ } \\
\text { incompetence }\end{array}$ & 36 & 14.2 & $\begin{array}{l}\text { no/few jobs/ } \\
\text { companies }\end{array}$ & 34 & 10.1 \\
\hline \multirow{3}{*}{$\begin{array}{l}\text { no/few jobs/ } \\
\text { companies }\end{array}$} & \multirow[b]{2}{*}{26} & \multirow{2}{*}{7.9} & \multirow{2}{*}{$\begin{array}{l}\text { desolate town, } \\
\text { ageing population } \\
\text { (young people } \\
\text { have left) }\end{array}$} & \multirow{2}{*}{34} & \multirow{2}{*}{13.4} & too big a town & 27 & 8 \\
\hline & & & & & & linguistic barrier & 27 & 8 \\
\hline & & & $\begin{array}{l}\text { infrastructure } \\
\text { shortage }\end{array}$ & 17 & 6.7 & $\begin{array}{l}\text { infrastructure } \\
\text { shortage }\end{array}$ & 18 & 5.3 \\
\hline Total & 327 & 100 & Total & 253 & 100 & total & 337 & 100 \\
\hline
\end{tabular}

23 The examined were asked, "What are, in your opinion, disadvantages of living in Görlitz/Guben/ Frankfurt? Please, enumerate maximum three disadvantages" (open-ended question). 


\section{Conclusions}

In 1991, Ewa Nowicka wrote that Poles were "relatively well" familiar with Germans, not only because of the neighbourhood and the significance of the social and civilizational contact but also "the tradition of hostility and animosity in mutual contacts, which had been enhanced by the experience of the WWII" (Nowicka 1991: 177). This component of hostility, but simultaneously also of strength and military power, was historically a part of the German stereotype in the eyes of Poles, being of complex character, though: it was composed, next to the negative elements mentioned above, of positive elements accentuating civilizational superiority, higher culture (Wrzesiński 2007: 15).

Wojciech Wrzesiński concludes that in the light of the historical research it is known that "stereotypes of Germans held by Poles were, however, dependent not only on direct historical experiences but also on real differences - mutual civilizational, cultural, economical, those of evaluation of power, efficiency and richness of both nations, along with a certain degree of conflicts in reciprocal relations observed over long duration" (Wrzesiński 2007: 21). Of particular importance seems to be the evaluation of Polish-German relations at the interstate level; at the moment when our research was taking place, it was possible to reckon these relations as friendly. It has been 25 years since the Treaty of Good Neighbourhood and Friendly Cooperation was signed, preceded by gestures of reconciliation between the Polish and German nations. Here we can recall the 1965 Letter of Reconciliation of the Polish Bishops to the German Bishops with the words: "we forgive and ask for forgiveness", and the German response to it (cf. Dec-Pustelnik 2015), as well as Willy Brandt kneeling in 1970 in front of the Warsaw Ghetto Memorial. In the context of today's positive Polish-German neighbourliness, practiced in various areas (macro, micro, cooperation within Euroregions, twin towns located at greater distance from each other), the significance of the negative components of the image of Germans, especially those elements that are directly involved in the context of WWII, are weakening. This is attested to by the positively evaluated features of Germans, positive emotions towards them (including "warm indifference"24) and openness to Germans fulfilling various social roles, as neighbours, friends, cooperators, and even family members.

As for the negative perceptions of Germans - as an enemy and a dominating aggressor, historically evidenced and recorded in literature - nowadays we have to deal at most with their aftermath in a nuanced form: reckoning Germans as swaggering, running the show or being arrogant. One does not meet, however, such labels as "enemy", or "Hitlerites". Hence we are tempted to apply two interpretations here. Firstly, our respondents do not reveal their fears, as they take a relativistic view of them in the context of their own everyday experience (it would be difficult to feel fear and meet a German enemy every day). Secondly, perhaps

24 The category of "warm indifference", introduced by Dębicki and Doliński to describe the attitude of the inhabitants of Zgorzelec to those of Görlitz, underlines the fact that the borderlanders declaring an indifferent attitude to their German neighbours quite often ascribe to them positive features, yet their intensity is shifted from the category of "definitely" to "rather", with incidental appearance of negative features that compose the stereotype of Germans (Dębicki, Doliński 2013). 
owing to the lapse of time, the historical experience no longer matters in judging a German neighbour. And so, referring to Joanna Kurczewska's considerations, one may say that the inhabitants of the Polish parts of the divided towns are not oriented towards the borders as there is no enemy on the other side of them, but to the borderland, as there is the "Other" that does mean something to these borderlanders.

As for the material space, the German environment, it needs to be underlined that it is also positively evaluated, which is revealed in the fact that half of the inhabitants of Zgorzelec, Gubin and Stubice declare a readiness to move and live on the other side of the border. Moreover, regardless of this declared willingness, our respondents tend to see many more advantages than disadvantages of living across the border. One should pay attention, though, to the fact that respondents are attracted by such pluses as developed infrastructure, spatial order and a broadly conceived higher standard of living, i.e. the factors that positively influence the quality of life on a local and state level, and not by the very people. Germans themselves and their attributes are valued lower, as factors that do not attract; we cannot, however, say that they - as it might seem - constitute a repelling factor, since they make no barriers that would restrain respondents from living among Germans.

How, then, in the context of the question posed at the beginning of the article, shall we interpret the results presented above? The following answer emerges: the German neighbour is no "Stranger" to the inhabitants of Zgorzelec, Gubin and Stubice. This is evidenced, firstly, by the low level of antipathy towards Germans and at the same time the higher level of liking and indifference as compared to the IPA's nationwide data. Secondly, the characteristics that are mostly of a positive implication dominate the way German neighbours tend to be described. At the same time, respondents notice the Germans' dissimilarity, and the social distance can be traced in the reported advantages and disadvantages of living on the other side of the border, mainly in the dominance of the category of "human factor" among the disadvantages. However, it should be noted that there is no sense of strangeness in it a German tends to be recognized, predictable, and is not defined as enemy and so poses no threat. This is testified by everyday practices - mass border crossings, maintaining a broad spectrum of social relations (including those of an autotelic character, on private, personal terms) and dispositions in favour of these practices, e.g. positive evaluation of the neighbours (taking into account a wide spectrum of characteristics and not just common, stereotypical opinions about them), openness to them, and some respondents' willingness to move and live in Görlitz, Guben and Słubice.

One may thus conclude that the German neighbour in the borderland is a "tamed" German, "a familiar Other", and the context through which his/her image is shaped is surely constituted by everyday experiences that prompt respondents to reinterpret historically rooted classifying schemes and to grant dissimilar meanings to the differences noticed, as well as, simultaneously, to transform their own approach to Germans. 


\section{References}

ALEXANDER, Jeffrey C. 2004. "Rethinking Strangeness: From Structures in Space to Discourses in Civil Society." Thesis Eleven 79(1): 87-104.

BOSKI, Paweł. 2010. Kulturowe ramy zachowań społecznych. Podręcznik psychologii międzykulturowej [Cultural framework of social behaviour. An intercultural psychology coursebook]. Warsaw: Wydawnictwo Naukowe PWN.

BUCHOLC, Marta. 2010. "Dehumanizujący wymiar obcości i jej etyczna niezbędność. Na marginesie Obcego Georga Simmla." [The Dehumanizing Dimension of Strangeness and Its Ethical Indispensability in George Simmel's The Stranger]. Etyka 43: 64-76.

CHLEBOWCZYK, Józef. 1975. Procesy narodotwórcze we wschodniej Europie Środkowej w dobie kapitalizmu [Nation-building processes in Central Europe in the capitalist era]. Warsaw/Cracow: PWN.

CIOK, Stanisław. 1992. "Polska granica zachodnia. Zmiana funkcji granicy.” [Poland's western border. A change of border function]. Pp. 9-21 in Problemy społeczno-gospodarcze miast pogranicza polsko-niemieckiego [Socio-economic problems of the towns in the Polish-German borderland], edited by Zbigniew KURCZ. Wrocław: Wydawnictwo Uniwersytetu Wrocławskiego.

DEC-PUSTELNIK, Sylwia. 2015. “List biskupów.” [Bishops' Letter of Reconciliation]. Pp. 424-432 in Interakcje. Leksykon komunikowania polsko-niemieckiego [Interactions. A lexicon of the PolishGerman communication], edited by Alfred GALL, Jacek GRĘBOWIEC, Justyna KALICIŃSKA, Kornelia KOŃCZAL and Izabela SURYNT. Wrocław: Atut.

DENZIN, Norman, K. 2009. The Research Act: A Theoretical Introduction to Sociological Methods. London: Aldine Transaction.

DĘBICKI, Marcin and Wojciech DOLIŃSKI. 2013. "Sympatia i 'ciepła obojętność' jako kategorie analityczne stosunku zgorzelczan do mieszkańców Görlitz." [Liking and "warm indifference" as analytical categories of the attitude of the inhabitants of Zgorzelec towards the inhabitants of Görlitz]. Opuscula Sociologica 2: 7-30.

DĘBICKI, Marcin and Julita MAKARO. 2017. "German Neighbours in the Ryes of the Inhabitants of Gubin: An Analysis of Stereotypes in the Polish-German Twin Town." Pp. 345-369 in Advances in European Borderlands Studies, edited by Elżbieta OPIŁOWSKA, Zbigniew KURCZ and Jochen ROOSE. Baden-Baden: Nomos.

DOLIŃSKA, Kamilla. 2016. “O wielokulturowości pożądanej i niepożądanej w polskim kontekście wymiar narodowy i lokalny." [On desired and undesired multiculturalism in the Polish context national and local dimension]. Pp. 425-442 in Polityczne i spoleczne aspekty wielokulturowości wielokulturowości. Migracje i mniejszości [Political and social aspects of multiculturalism. Migrations and minorities], edited by Anita ADAMCZYK, Andrzej SAKSON and Cezary TROSIAK. Poznań: WNPiD UAM.

DOLIŃSKA, Kamilla. 2013. "Teoretyczne i metodologiczne aspekty badania sąsiedztwa na pograniczu." [Theoretical and methodological aspects of the research into neighbourhood in the borderland]. Pp. 241-258 in Sasiedztwa III RP - Czechy. Zagadnienia społeczne [Polish neighbourhoods the Czechia. Social issues], edited by Marcin DĘBICKI and Julita MAKARO. Wrocław: GAJT Wydawnictwo.

DOLIŃSKA, Kamilla and Julita MAKARO. 2015. "Wielokulturowość Wrocławia i stosunek jego mieszkańców do Innych." [The city's multicultural and attitude of residents of Wroclaw to Other]. Pp. 70-101 in Uczestnicy, konsumenci, mieszkańcy. Wroctawianie i ich miasto w ogladzie socjologicznym [Participants, consumers, residents. Wroclaw's residents and their city in the sociological view], edited by Mateusz BŁASZCZYK and Jacek PLUTA. Warsaw: Scholar. 
DOLIŃSKA, Kamilla and Natalia NIEDŹWIECKA-IWAŃCZAK. 2016. "Mieszkańcy pogranicza zachodniego o niemieckich sąsiadach a Polacy o Niemcach." [The residents of Poland's western borderland about their German neighbours and Poles about Germans]. Pogranicze. Studia Społeczne 27(2): 223-245.

DOLIŃSKA, Kamilla and Natalia NIEDŹWIECKA-IWAŃCZAK. 2014. “Atrakcyjność niemieckich części miast podzielonych Zgorzelec-Görlitz i Gubin-Guben w percepcji zgorzelczan i gubinian.” [The attractiveness of Görlitz and Guben for inhabitants of Zgorzelec and Gubin]. Pp. 199-216 in Polskie pogranicza $w$ procesie przemian, Tom III. [Polish borderlands in the process of change. Vol. III] , edited by Zbigniew KURCZ. Wrocław: Wydawnictwo Uniwersytetu Wrocławskiego.

DOLIŃSKA, Kamilla and Natalia NIEDŹWIECKA-IWAŃCZAK. 2015. "Zgorzelec and Gubin-Between Polish Peripheries and a Cross-border Center.” Pp. 128-150 in Microcosm of European Integration: The German-Polish Border Regions in Transformations, edited by. Elżbieta OPIŁOWSKA and Jochen ROOSE. Baden-Baden: Nomos.

DOLIŃSKA, Kamilla, Julita MAKARO and Natalia NIEDŹWIECKA-IWAŃCZAK. 2016. "Od miast przygranicznych do miast pogranicza? Wybrane miasta pogranicza zachodniego w świetle analiz socjologicznych." [From frontier towns to borderland towns? Selected towns of the western borderland in the light of sociological analyses]. Pp. 361-382 in Co po kryzysie? [After the crisis], edited by Grażyna SKĄPSKA, Marek S. SZCZEPAŃSKI and Żaneta STASIENIUK. Warsaw: PTS.

DOLIŃSKA, Kamilla, Julita MAKARO and Natalia NIEDŹWIECKA-IWAŃCZAK. 2013. "Instrumentalność vs. autoteliczność praktyk transgranicznych mieszkańców Zgorzelca i Gubina." [Instrumental versus autotelic character of the cross-border practices of the inhabitants of Zgorzelec and Gubin]. Opuscula Sociologica 2: 31-46.

DONNAN, Hastings and Thomas M. WILSON. 1999. Borders, Frontiers of Identity, Nation and State. New York: Berg.

GOŁDYKA, Leszek. 2013. Pogranicze polsko-niemieckie jako przestrzeń socjalizacji [Polish-German borderland as a space of socialization]. Warsaw: Wydawnictwo Naukowe Scholar.

GOŁDYKA, Leszek, Jerzy LESZKOWICZ-BACZYŃSKI, Lech SZCZEGÓŁA and Maria ZIELIŃSKA. 1997. "Wprowadzenie." [Introduction]. Pp. 7-9 in Transgraniczność w perspektywie socjologicznej [Transborderness in a sociological perspective], edited by Leszek GOŁDYKA, Jerzy LESZKOWICZ-BACZYŃSKI, Lech SZCZEGÓŁA and Maria ZIELIŃSKA. Zielona Góra: Lubuskie Towarzystwo Naukowe.

JAROSZEWSKA, Emilia. 2015. "Małżeństwa polsko-niemieckie." [Polish-German neighbourhoods]. Pp. 495-510 in Interakcje. Leksykon komunikowania polsko-niemieckiego [Interactions. A lexicon of the Polish-German communication], edited by Alfred GALL, Jacek GRĘBOWIEC, Justyna KALICIŃSKA, Kornelia KOŃCZAL and Izabela SURYNT. Wrocław: Atut.

KNIPPSCHILD, Robert and Anja SCHMOTZ. 2015. "Seizing the Opportunities of European Integration? Quality of Life and Cross Border Interrrelations in the German-Polish Border Region.” Pp. 92-127 in Microcosm of European Integration: The German-Polish Border Regions in Transformations, edited by Elżbieta OPIŁOWSKA and Jochen ROOSE. Baden-Baden: Nomos.

KOZERA, Bartłomiej. 1999. “'Obcy’ i 'swój'. Trzy refleksje rozumu nieinstrumentalnego.” [“Stranger” and "Insider". Three reflections of an uninstrumental reason]. Pp. 39-48 in Inni swoi. Studia z problematyki etnicznej [Others insiders. Studies on ethnic issues], edited by Danuta BERLIŃSKA and Krzysztof FRYSZTACKI. Katowice: Wydawnictwo Instytut Śląski.

KURCZ, Zbigniew. 2008. "Przedmiot socjologii pogranicza w świetle polskich doświadczeń." [The subject of the sociology of borderland in the light of the Polish experiences]. Pp. 19-27 in Polskie pogranicza $w$ procesie przemian. Tom III [Polish borderlands in the process of change. Vol. III], edited by Zbigniew KURCZ. Wałbrzych: WWSZiP. 
KURCZ, Zbigniew. 2009. “O transgraniczu i transgraniczności. Wprowadzenie.” [On transborderland and transborderness. Introduction]. Pp. 9-18 in Polskie transgranicza [Polish transborderlands], edited by Zbigniew KURCZ and Andrzej SAKSON. Wrocław: Wydawnictwo Uniwersytetu Wrocławskiego.

KURCZEWSKA, Joanna. 2005. “Granica niejedno ma imię. Trzy podejścia teoretyczne.” [Border has more than just one name. Three theoretical approaches]. Pp. 365-396 in Granice na pograniczach [Borders in borderlands], edited by Joanna KURCZEWSKA and Hanna BOJAR. Warsaw: Wydawnictwo IFiS PAN.

ŁADA, Agnieszka. 2016. Barometr Polska - Niemcy 2016. Polacy I Niemcy o sobie nawzajem 25 lat po podpisaniu Traktatu o dobrym sąsiedztwie i przyjaznej wspótpracy [The 2016 Poland Germany barometer. Poles and Germans about each other 25 years after signing the Treaty of Good Neighbourship and Friendly Cooperation]. Warsaw: ISP.

ŁADA, Agnieszka and Justyna SEGEŠ-FRELAK, eds. 2012. Eine Grenze verschwindet. Die neue polnische Migration nach Deutschland aus lokaler Perspektive. Warsaw: Institut für Öffentliche Angelegenheiten.

MAKARO, Julita. 2007. Gubin - miasto graniczne. Studium socjologiczne [Gubin - a border city. A sociological study]. Wrocław: Wydawnictwo Uniwersytetu Wrocławskiego.

NEWMAN, David and Anssi PAASI. 1998. "Fences and Neighbours in the Postmodern World: Boundary Narratives in Political Geography.” Progress in Human Geography 22(2): 186-207.

NIEDŹWIECKA-IWAŃCZAK, Natalia. 2011. “Transgraniczność w praktykach mieszkańców Zgorzelca." [Transborderness in the practices of inhabitants of Zgorzelec]. Pp. 47-71 in Zgorzelec jako miasto pograniczne $w$ opiniach jego mieszkańców [Zgorzelec as a borderland town in the opinions of its inhabitants], edited by Kamilla DOLIŃSKA and Natalia NIEDŹWIECKAIWAŃCZAK. Wrocław: GAJT Wydawnictwo.

NOWICKA, Ewa. 1991. "Dystans wobec Niemców w społeczeństwie polskim.” [Distance towards Germans in the Polish society]. Kultura i Społeczeństwo 4: 167-177.

NOWICKA, Ewa and Sławomir ŁODZIŃSKI. 2001. U progu otwartego świata [On the threshold of an open world]. Cracow: NOMOS.

OPIŁOWSKA, Elżbieta. 2009. Kontinuitäten und Brüche deutscher Erinnerungskulturen. GörlitzZgorzelec 1945-2006. Dresden: Neiss-Verlag.

OPIŁOWSKA, Elżbieta. 2010. "Erinnerungspolitik im deutsch-polnischen Grenzgebiet nach dem Zweiten Weltkrieg." Inter Finitimos. Jahrbuch zur deutsch-polnischen Beziehungsgeschichte 8: $101-118$.

OPIŁOWSKA, Elżbieta. 2015a. "Granica państwowa / pogranicze.” [The state border / borderland]. Pp. 201-212 in Interakcje. Leksykon komunikowania polsko-niemieckiego [Interactions. A lexicon of the Polish-German communication], edited by Alfred GALL, Jacek GRĘBOWIEC, Justyna KALICIŃSKA, Kornelia KOŃCZAL and Izabela SURYNT. Wrocław: Atut.

PALECZNY, Tadeusz. 2007. Interpersonalne stosunki międzykulturowe [Intercultural interpersonal relations]. Cracow: Wydawnictwo Uniwersytetu Jagiellońskiego.

SADOWSKI, Andrzej. 1995. "Socjologia pogranicza." [Borderland sociology]. Pp. 133-139 in Ludzie i instytucje. Stawanie sie ładu społecznego. Pamiętnik IX Ogólnopolskiego Zjazdu Socjologicznego, Tom. 2 [People and institutions. Social order in progress. The memoir of the IX. Polish Sociological Congress, vol. 2], edited by Antoni SUŁEK, Józef STYK and Irena MACHAJ. Lublin: Wydawnictwo Uniwersytetu Marii Curie-Skłodowskiej.

SADOWSKI, Andrzej. 1996. "Od miast przygranicznych do miast pogranicza." [From frontier towns to borderland towns]. Pogranicze. Studia Spoleczne 5: 5-24.

SADOWSKI, Andrzej. 2014. "Socjologia pogranicza w warunkach społeczeństwa pluralistycznego." [Borderland sociology under the conditions of a pluralistic society]. Pp. 103-121 in Transgraniczność 
w perspektywie socjologicznej. Pogranicza i centra współczesnej Europy [Transborderness in a sociological perspective. Contemporary Europe's borderlands and centres], edited by Maria ZIELIŃSKA and Beata TRZOP. Zielona Góra: Lubuskie Towarzystwo Naukowe.

SIMMEL, Georg. 1950. “The Stranger.” Pp. 402-408 in The Sociology of Georg Simmel, edited by Kurt H. WOLFF. New York: Free Press of Glencoe.

STICHWEH, Rudolf. 1997. "The Stranger - On the Sociology of the Indifference.” Thesis Eleven 51(1): $1-16$.

SZLACHCICOWA, Irena. 1999. "Tożsamość mieszkańców polsko-niemieckiego pogranicza w Euroregionie Nysa." [Sense of identity of the inhabitants of the Polish-German borderland in the Euroregion Neisse]. Pp. 71-82 in Pogranicze z Niemcami a inne pogranicza Polski [The borderland to Germany and Poland's other borderlands], edited by Zbigniew KURCZ. Wrocław: Wydawnictwo Uniwersytetu Wrocławskiego.

WASTL-WALTER, Doris, ed. 2011. The Ashgate Research Companion to Border Studies. Farnham, UK: Ashgate Publishing.

WOJAKOWSKI, Dariusz. 2005. "Swojskość i obcość na pograniczu - strategie interpretacyjne granic grup społecznych." ["Familiarity" and "Strangeness" in borderland - strategies to interpret the borders of social groups]. Pp. 37-65 in Granice na pograniczach [Borders in borderlands], edited by Joanna KURCZEWSKA and Hanna BOJAR. Warsaw: Wydawnictwo IFiS PAN.

WRZESIŃSKI, Wojciech. 2007. Sąsiad. Czy wróg? Ze studiów nad ksztattowaniem obrazu Niemca w Polsce w latach 1795-1939 [A neighbour or enemy? Studies on shaping a picture of Germans in Poland 1795-1939]. Wrocław: Wydawnictwo Uniwersytetu Wrocławskiego.

\section{Authors}

Kamilla Dolińska is Assistant Professor in the Department of Sociology of Borderlands at the Institute of Sociology at the University of Wrocław. Her research interests are national and ethnic minorities, Polish-German borderland, Polish national neighbourhoods and multiculturalism. She has coedited Zgorzelec jako miasto pograniczne $w$ opiniach jego mieszkańców [Zgorzelec - as a borderland city in the opinions of their residents] (2011 with N. Niedźwiecka-Iwańczak) and $O$ wielokulturowości monokulturowego Wrocławia [On Multiculturalism of Monocultural Wrocław] (2013 - with J. Makaro).

Contact: kamilla.dolinska@uwr.edu.pl

Natalia Niedźwiecka-Iwańczak is Assistant Professor at the Institute of Sociology, University of Wrocław. Her interests are focused on identity, ethnicity, borderland, divided towns. She is an author of book Etniczny aspekt tożsamości Łużyczan [The Ethnic Aspect of Identity of Sorbs] (2013); she has coedited (with K. Dolińska) a book Zgorzelec jako miasto pograniczne w opiniach jego mieszkańców [Zgorzelec - as a borderland city in the opinions of their residents] (2011).

Contact: natalia.niedzwiecka-iwanczak@uwr.edu.pl 